\title{
THE EFFECT OF USING COOPERATIVE SCRIPT ON STUDENT'S READING COMPREHENSION AT GRADE ELEVENT OF SMA NEGRI 2 PEMATANGSIANTAR Enji Putri Ivantara ${ }^{1}$, Herman $^{2}$, David Berthony Manalu ${ }^{3}$ \\ ${ }^{1,2,3}$ Universitas HKBP Nommensen (UHN), Medan, Indonesia enjiputri11@gmail.com¹ ,herman@uhn.ac.id ${ }^{2}$
}

\begin{abstract}
This study is about the effect of Cooperative Script on students' reading comprehension. Problem raised in this research was: What is the effect of using Cooperative Script on student's reading comprehension at Grade eleven of SMA Negeri 2 Pematangsiantar? To answer the question, experimental design was conducted to this research. The population of the study was the 2019/202 academic year firstsemester grade XI students of SMA Negeri 2 Pematangsiantar. The samples were two classes, namely XIPMIA3 and XIPIS 1, with the total was 68 students selected by applying random sampling. The sample was divided into two groups. Experimental group (XI PIS 1) was taught by applying Cooperative Script Method while the control group (XI PMIA 3) was taught by applying explaining method. There were two data used in this research. They were pre-test and post-test. The data were analyzed by using t-test formula to show the effect of applying Cooperative Script Method on students' reading comprehension. After analyzing the data, the finding indicates that t-observed was higher than t-table (6.263 > 1.668)) with the degree of freedom $(d f)=66$. It means that applying Cooperative Script Methodhas significantly affected students' reading comprehension.
\end{abstract}

Keywords: article; cooperative script, method, reading comprehension, recount text

\section{INTRODUCTION}

Language is one of the tools used by everyone in their daily life as a means to convey information and arguments to others. Without language, people cannot interact with other people. According to Pasaribu, Herman and Hutahaean (2020:12), language is a complex system of communication that used human beings. By language we can talk with other people, can give information, can able to exchange knowledge, can express emotion, ideas, beliefs, feelings, opinions, wishes, thanks, and promises From many of languages in the world, English is a global language that is used as a communication device between nations of different language.

English plays an important role in process of communication among them and also English can accelerate science and technological development of a nation. In teaching English, there are four skills that have to be mastered by the students; listening, writing, reading and speaking. 
English has four basic language skills, they are listening, speaking, writing, and reading. Sandiku (2005:29) defined the four skills as: Listening and Speaking: these two skills are highly interrelated and work simultaneously in a real life situation. So, the integration of the two aims at fostering effective oral communication. Reading and Writing: they form a strong relationship with each other as a skill. They are tools for achieving effective written communication. The researcher can conclude that the four basics of English cannot be separated because they are related to another. Four of them have to be mastered by someone who learns English. Reading is one of the four skills in English that has an important contribution to the success of learning this language. According to Sandiku (2005:30) stated that "Through reading, we learn a lot and it is the most prominent language skill. "Reading is related with daily life because people read many kinds of written materials such as newspaper, magazines, academic book, and so on. Reading can help people to get any information, knowledge, and even problem solution. So reading is very important to the learner.

In this era, students are always using the internet to get information and on the internet often contain the English language in an advertisement or in the information. Furthermore, in this era, all the students only know to read but difficult to comprehend. Moreover reading needs more comprehension, because "Reading" is different with "Reading Comprehension". Reading use eye but Reading Comprehension needs heart. So, reading comprehension can be defined as reading by the eyes of the heart. Reading related to comprehension or understanding. The people get information for reading when they can understand the context of reading. It means that comprehension or understanding something is the main goal of reading. The reading comprehension is very important to a student so the English teacher should make the reading learning process joyful and interest to a student. The English teacher can make the joyful and interest learning process use the strategy that appropriates to student or class atmosphere, use the interest media to make the student more attention and interest with the learning process.

In fact, many students do not master the reading comprehension because of many problems. The problems can appear from students and teacher. The problems that appears from students are less vocabulary, not interest with reading learning process or materials reading. The problem that appear from the teacher like not use media, strategy, technique and material reading that not appropriate to student or class atmosphere.

Based on the researcher's experience in her teaching practice of eleven grade at SMA Negeri 2 Pematangsiantar. The researchers found that the students' reading comprehension was still low. By checking the mean score of the students' reading comprehension was 60 . According 
the data that researcher found while teaching practice in SMA Negeri 2 Pematangsiantar. This score was categories as poor level based on The Dirjen Pendidikan Dasar dan Menengah classification (2005:25), the minimum completeness criteria for students is 75 . It was found when the students studied reading in the class. Most of them did not competent to comprehend English text well. Many students could read the word in passage perfectly but were unable to answer the questions. They could say the words, but they were unable to gain the meaning from words. They found hard to comprehend reading materials. The researcher also found that the teacher only asked the students to read, and then they had answered the question without giving explanation about the text first. Therefore the students did not understand what they read. As a result, they could not answer the whole questions correctly. In this case, the students have to read critically, and the teacher must select the suitable technique or strategy to teach it.

To solve the problems above, there are some methods in teaching to make learning process in the classroom become more interesting and even fun. One of them is Cooperative Learning. According to Bolukbas, Keskin, and Polat (2011:331), "Cooperative learning is a learning method in which learners help each other in terms of their learning process by making up small homogenous group to achieve a common goal, and in which group performance is rewarded in several different ways". According to Majid (2014), there are any purpose of implementing cooperative learning It increases students' performance in accomplishing academic assignments. Besides that, it helps the students to understand complex concepts. One method of cooperative learning which is suitable in teaching reading comprehension is cooperative script. According to Slavin (1996:29) as cited by Riska, Marahaeni and Suputra (2018) states "Cooperative scripts is a term for the practice of two students working together to summarize material and support one another's understanding and recall of the important facts and concepts contained in the material read". Based on the explanation above, the researchers raised a question for: What is the effect of using cooperative script on Students' reading comprehension at Grade eleven of SMA Negeri 2 Pematangsiantar."

\section{METHOD}

\section{A.Research Design}

This research uses experimental quantitative design. According to Creswell (2011:4) a quantitative research is a mean for testing objective theories by examining the relationship among variables. This research method is used to describe variables, to examine relationships among variables and to determine cause-and-effect interactions between variables (Burns \& 
Grove, 2005:23 as cited in Herman, Sibarani and Pardede, 2020:87). These variables, in turn can be measured, typically on instruments so that numbered data can be analyzed using statistical procedures. A quantitative research strives for testable and confirmable theories assumption. It seeks scientific explanation that includes the discovery of laws governing not only the behavior. The final written report has a set structure consisting of introduction, literature and theory, method, result and discussion.

Furthermore, the data are taken by using the experimental design. According to Cohen\& Elizabeth (2007:270) experiment research is to test the impact of a treatment or intervention on an outcome, controlling for all other factors that might influence that outcome. In conducting the experimental research, the sample will be divided into two groups, namely experimental group and control group. It is figured as following:

Table 1. Table of research design

\begin{tabular}{|l|l|l|l|}
\hline Group & Pretest & Treatment & Post test \\
\hline Experimental & $\mathrm{x}_{1}$ & $\mathrm{X}$ & $\mathrm{x}_{2}$ \\
\hline Control & $\mathrm{y}_{1}$ & $\mathrm{Y}$ & $\mathrm{y}_{2}$ \\
\hline
\end{tabular}

Notes:

$\mathrm{X} \quad$ : The application of cooperative script

Y : The application of explaining method

$\mathrm{x}_{1}, \mathrm{y}_{1}$ : Pre-test in experimental and control group

$\mathrm{x}_{2}, \mathrm{y}_{2}$ : Post-test in experimental and control group

\section{B. Population and Sample}

\section{Population}

According to Sihombing (2019:37) stated that sample is the small proportion that is taken from population or analytical needing. Based on the statement it is implied that not all population is necessary involve in the study but only in the certain number of students are selected as representative. Before the sample is collected, the researcher has to determine the population. According to Ary, Jacobs, and Sorensen (2010:167), Population is defined as all members of any well-defined class of people, events or objects.

The population of this research is grade eleventh students of SMA N 2 Pematangsiantar. There are eleven parallel classes, seven of them are Science program, and the others are Social program. Each class consists of 30 up to 40 students, total are 385 students. Below is the table of the population of the grade eleven students of SMAN 2 Pematangsiantar. 
Table 2. The population of grade eleven students of SMA N 2 Pematangsiantar.

\begin{tabular}{|c|c|}
\hline Classes & Total population \\
\hline XI SCIENCE 1 & 37 \\
\hline XI SCIENCE 2 & 38 \\
\hline XI SCIENCE 3 & 35 \\
\hline XI SCIENCE 4 & 36 \\
\hline XI SCIENCE 5 & 33 \\
\hline XI SCIENCE 6 & 35 \\
\hline XI SCIENCE 7 & 37 \\
\hline XI SOCIAL 1 & 38 \\
\hline XI SOCIAL 2 & 35 \\
\hline XI SOCIAL 3 & 36 \\
\hline XI SOCIAL 4 & 37 \\
\hline TOTAL & 385 students \\
\hline
\end{tabular}

The researcher chooses the second grade students because they are learning some kinds of text in this year and one of them was Report text.

\section{Sample}

Creswell (2011:142) defined sample is a subgroup of the target population that the researcher plans to study for the purpose of making generalization about the target population. The sample of this research is two classes which are XI-IA3 a control class because they are active with better achievement than other class and XI-IA4 as an experimental class because they have lower achievement. It can be proved based on the previous explanation in background that average of score that the students get when the teacher gives the test is 60. Even though the minimum completeness criteria (KKM) determined by the school in English subject is 70.

This class is suitable to applied Cooperative Script to improve their achievement.

Table 3. Total of the sample students

\begin{tabular}{|c|c|c|}
\hline Group & Class & Students \\
\hline Control & XI-IA3 & 35 \\
\hline Experimental & XI-IA4 & 36 \\
\hline Total & & 71 Students \\
\hline
\end{tabular}

\section{The Instrument of Collecting Data}

\section{Test}

The instrument of this research is a test. According to Ary, Jacobs and Sorensen (2010:201), a test is a set of stimuli presented to an individual in order to elicit responses on the basis of which a numerical score can be assigned. The test used is fill in the blank test intended to measure writing ability of students. There are two kind of test used to collect the data; pre-test 
and post-test. The researcher chooses test for collecting the data is by using fill the blank test in pre-test and post-test. There will be 20 questions.

\section{Scoring the Test}

The researcher conduct the test consist of 20 questions, with the score as follows:

$$
\text { Students' score }=\frac{\text { Accepted Score }}{\text { Maximal Score }} \times 100
$$

(Arikunto, 2009:236)

\section{Table 4. The criteria of the scores}

\begin{tabular}{|c|c|c|}
\hline No & Items & Criteria \\
\hline 1. & $80-100$ & Very Good \\
\hline 2. & $70-79$ & Good \\
\hline 3. & $60-69$ & Fair \\
\hline 4. & $0-59$ & Fail \\
\hline
\end{tabular}

\section{Media}

There are some media that researcher using in this research;

a) Handphone, the researchers use handphone in this research to takes a picture during the treatment as the research documents.

b) Video Player by YouTube, the researcher using video to help the students understand about the text more clearly, the video that will be play related with the topic of the text.

c) The other documents as the instrument of the research are the lesson plans, class materials, the paper test and examination paper that collect during the research.

\section{Technique of Data Collection}

There were some steps in collecting the data for this research. For data collection technique researcher used test. Test is used to measure the competence of a person and also to achieve the objective. The data was collected by giving vocabulary test. The test was conducted twice.

\section{Pre-Test}

Pre-test was given to both experiment and control group. This text was conducted to find out whether the two groups are relatively equal in reading comprehension. 


\section{Treatment}

After the pre-test was conducted, treatment was given to experimental group. They were taught by using Cooperative Script Method while the control group was taught by using explaining method. Both groups were taught the same material. The teaching procedure can be seen as the following:

\section{Table 4. Teaching procedure in Experimental Group (Cooperative Script Method)}

\begin{tabular}{|c|c|}
\hline Teacher's Activity & Students' Activity \\
\hline $\begin{array}{l}\text { 1. Giving each students a text which is } \\
\text { going to be read }\end{array}$ & 1. Receiving the text given \\
\hline $\begin{array}{l}\text { 2. Asking the students to work in pair } \\
\text { after reading the first section }\end{array}$ & 2. Students working in pair \\
\hline $\begin{array}{l}\text { 3. Asking one student recalls the text } \\
\text { information without using the text. }\end{array}$ & 3. Doing the teacher's instruction \\
\hline $\begin{array}{l}\text { 4. Asking the other one provides } \\
\text { feedback without looking the text }\end{array}$ & 4. Doing the teacher's instruction \\
\hline $\begin{array}{l}\text { 5. Ask both partners elaborate on the } \\
\text { text information }\end{array}$ & 5. Discussing the text information \\
\hline $\begin{array}{l}\text { 6. Asking the couples read the second } \\
\text { section of the text and switch roles }\end{array}$ & 6. Doing the teacher's instruction \\
\hline $\begin{array}{l}\text { 7. After all of the section is finished, } \\
\text { the teacher giving a complete } \\
\text { summary of the text. }\end{array}$ & 7. Paying attention to the teacher, \\
\hline $\begin{array}{l}\text { 8. Asking the students to do the } \\
\text { evaluation individually }\end{array}$ & 8. Doing the evaluation \\
\hline
\end{tabular}

Table 5. Teaching Procedure in Control Group (Explaining Method)

\begin{tabular}{|c|c|}
\hline Teacher's Activity & Students' Activity \\
\hline $\begin{array}{l}\text { 1. Giving each student a text which is } \\
\text { going to be read. }\end{array}$ & 1. Receiving the text \\
\hline 2. Asking the students to read the text & 2. Reading the text \\
\hline $\begin{array}{l}\text { 3. Reading the first section of the text } \\
\text { and choose some students to read } \\
\text { the text aloud }\end{array}$ & $\begin{array}{l}\text { 3. Listening to the teacher (the } \\
\text { students who are asked to read, } \\
\text { read the text aloud. The other } \\
\text { listen to the one who read the text) }\end{array}$ \\
\hline $\begin{array}{l}\text { 4. Asking the students to find out the } \\
\text { meaning of difficult words }\end{array}$ & $\begin{array}{l}\text { 4. Finding out the meaning of } \\
\text { difficult words }\end{array}$ \\
\hline $\begin{array}{l}\text { 5. Asking the students to translate the } \\
\text { text }\end{array}$ & 5. Translating the text \\
\hline $\begin{array}{l}\text { 6. Asking the students to do the } \\
\text { evaluation individually }\end{array}$ & 6. Doing the evaluation \\
\hline
\end{tabular}




\section{Post-Test}

After the treatment, the same test was given to each group. This post-test was conducted to see the result whether the method is effective or not.

\section{E. Technique of Data Analysis}

After the researcher collect the data and then the researcher analyzes the data by following steps:

1. Finding mean score of each group

$$
\overline{\mathrm{X}}=\frac{\sum \mathrm{fx}}{\mathrm{N}} \quad \begin{aligned}
& \overline{\mathrm{X}}=\text { the average score } \\
& \sum_{\mathrm{N}} \mathrm{fx}=\text { sum of the raw score } \\
& =\text { number of students }
\end{aligned}
$$

2. Finding standard deviation of each group

$$
S=\frac{\sqrt{\sum d^{2}}}{\mathrm{~N}-1} \quad \begin{array}{ll}
S \quad=\text { standard deviation } \\
\sum d^{2}=\text { sum of mean deviation } \\
\mathrm{N} \quad=\text { number of students } \\
1 \quad=\text { constant number }
\end{array}
$$

(Hatch and Farhady, 1982:112)

3. Finding standard error of difference of mean

$$
\begin{aligned}
S E=(x e-x c)=\sqrt{\left(\frac{s e}{\sqrt{N 1}}\right)^{2}+\left(\frac{s c}{\sqrt{N 2}}\right)^{2}} \\
\qquad \begin{array}{l}
S E=(x e-x c)=\text { standard error } \\
s e=\text { standard deviation of experimental } \\
s c=\text { standard deviation of control } \\
N 1=\text { number students of experimental } \\
N 2=\text { number students of control }
\end{array}
\end{aligned}
$$

(Hatch and Farhady, 1982:59)

4. Testing Hypothesis

$$
t_{t e s t}=\frac{\bar{X} e-\bar{X} c}{S E(x e-x c)}
$$

$$
\begin{array}{ll}
\bar{X} e & =\text { Mean of post test in experimental } \\
\bar{X} c \quad=\text { Mean of post test in control } \\
S E(x e-x c)=\text { standart error }
\end{array}
$$

(Hatch and Farhady, 1982:59) 


\section{FINDING}

After analyzing the data, the researchers found that there was a significant effect of using Cooperative Script on the grade eleven students' reading comprehension ability at SMA Negeri 2 Pematangsiantar. To get the result of Pre-test in control and experimental class the researcher gives test multiple choices to the students that consists of 20 questions about report text. The researcher lead the students to answer the questions based on the explanation. To find the score the researcher used Arikunto theory, the result in Pre-test in Control and Experimental is Low, 69.559 in control and 63.382 experimental. Meanwhile, in got the post test the researcher gives a treatment to the students. In control group the researcher explain Report Text using Conventional method and in experimental class using Cooperative Script method. After the treatment the researcher gives a test to both of the class, they were asked to answer the multiple choice. Then, the researcher got the result of post test, to find the score the researcher used Arikunto theory, the result in post test in control 77.059 and in experimental class 87.5.

The difference or the improvement as the whole students got in post-test from control to experimental group is 445 or with the average 13.088. With the pre-test 63.382 and post-test is 87.5 in experimental group meanwhile pre-test is 68.55 and post-test is 77.05 in control group. The total sum squares of the respondents at the time of administering the post-test in experimental group is 1116,817 points where its standard deviation is 7.47. Meanwhile, the total sum squares of the respondents at the time of administering the post test in control group is 1515,238 points where its standard deviation is 8,70 .

To get the testing hypothesis, the researcher counting manual by using theory by Hatch

and Farhady, the formula is $t_{t e s t}=\frac{\bar{X} e-\bar{X} c}{S E(x e-x c)}$ The result of T-test is $\boldsymbol{t}_{\text {test }}=\mathbf{6 . 3 2 6}$. Testing hypothesis showed that t-test $(17.04)$ is higher than t-table $(1,68)$ at level of significance $5 \%$ for two tailed test. 


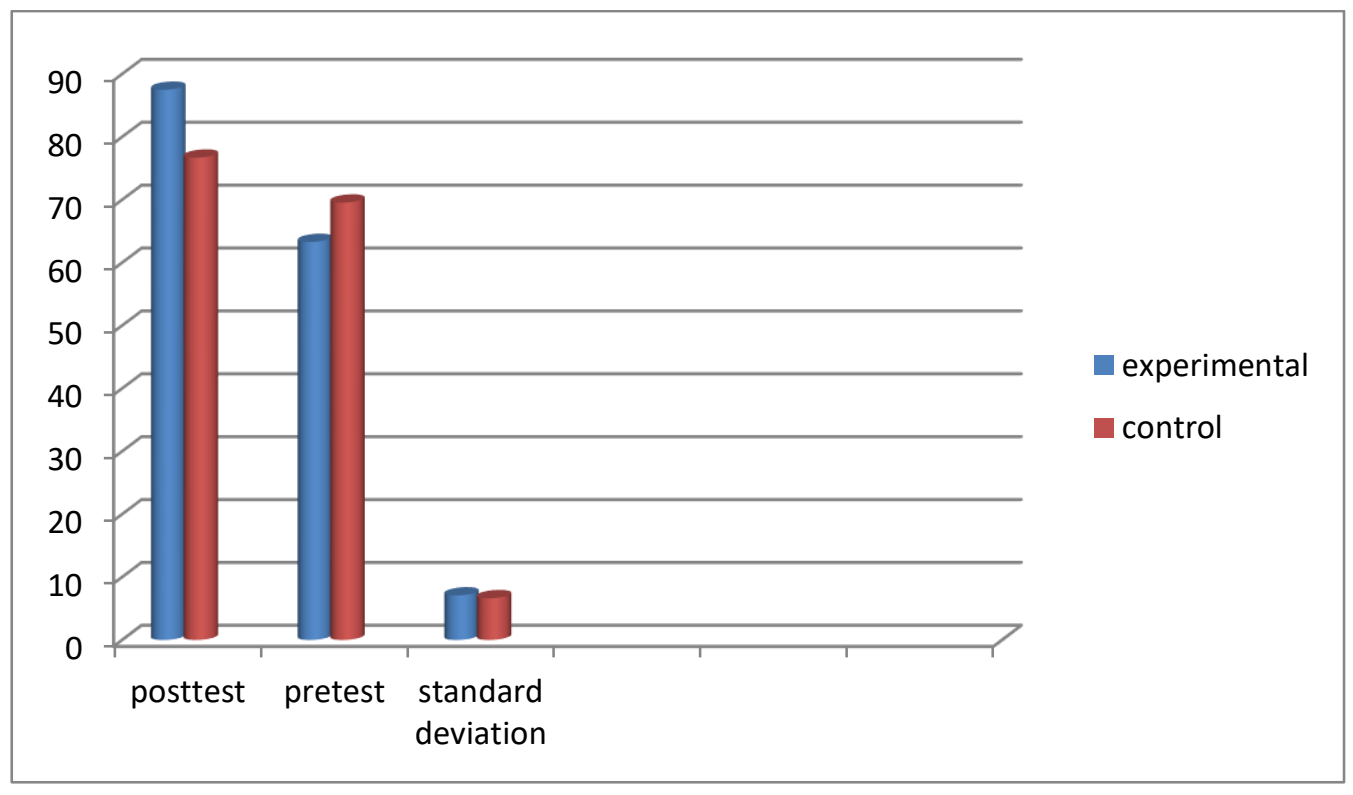

Chart 1. The Post-test, Pre-test and Standard deviation in experimental and control group.

Chart 1 above explains about the difference of post test, pre-test, and standard deviation of experimental and control class. We can see the comparison of the result in experimental and control. The score in pretest control higher than experimental, meanwhile the score in post test it's show the difference if experimental higher than control. For conclusion, we can see that students that used cooperative script have a higher score than use conventional method. In standard deviation, it show that control class higher than experimental class. It showed that cooperative script give the significant effect for students in reading comprehension.

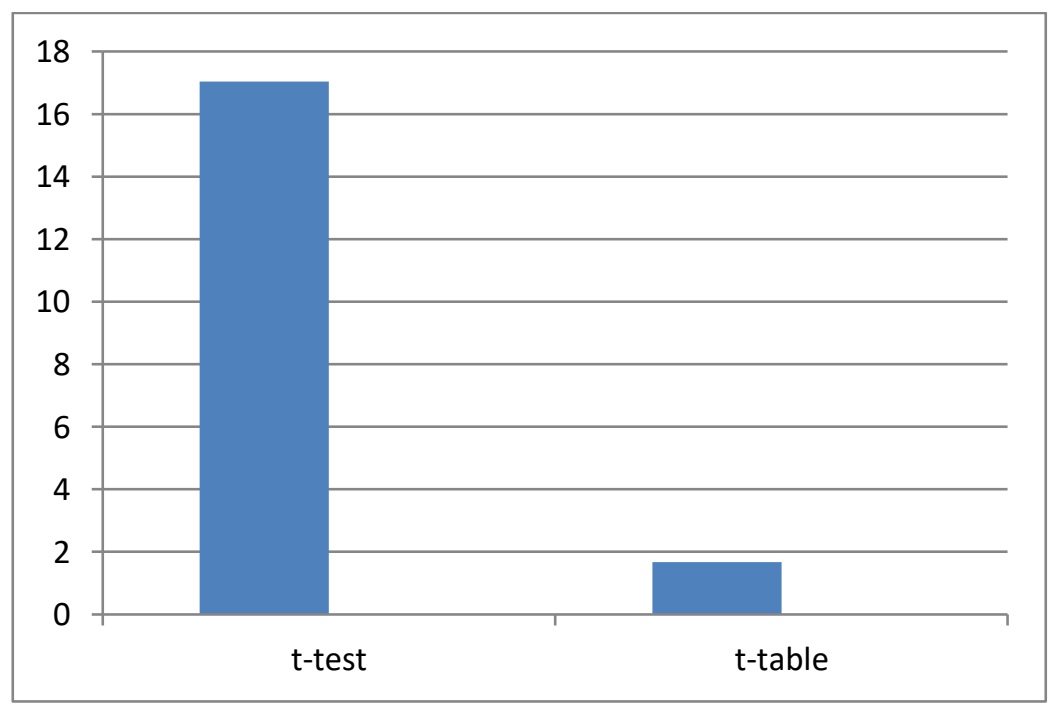

Chart2. The Difference of T-test and T-table 
In chart 2 above, Testing hypothesis showed that t-test (17.04) is higher than t-table $(1,68)$ at level of significance $5 \%$ for two tailed test. The result get by using manual calculation.

\section{DISCUSSION}

Previous related research done by Windha Agnesty (2018) has reported that the implementation of Cooperative Script Methodhas significantly affected students' reading comprehension. But the similarities in this research were the research done by Windha Agnesty (2018) used 4 different texts where each of them consists of 5 questions, so there were 20 questions. It is same with my research. Then, the method that used is Cooperative Script Method. The differnces in this research is the research done by Windha Agensty (2018) used sample in grade eleven only 60 students for each group 30 students. Meanwhile in my research the sample are 68 students.

After conducting the research in SMA Negri 2 Pematangsiantar the researcher found the differences in students' reading coomprehension between both of class which one that applied Cooperative Script Method and without using Cooperative Script Method. The finding of the research after analyzing the data the researcher finds the answer of the problem to find out what is the effect of using Cooperative Script method in teaching report text to improve students' reading comprehension and as the result the class that applied Cooperative Script Method have better achievement on their test especially in comprehend the text that used in reading comprehension.

\section{CONCLUSION}

After analyzing the data presented in the previous chapter, it is found out that using Cooperative Script significantly affects the students' reading comprehension at grade eleven SMA N 2 Pematangsiantar. It can be seen from the result showed that the value of t-test is higher than value of t-table. $(6.263>1.668))$ with the degree of freedom $(\mathrm{df})=66$. Based on the data analysis of the study, the result indicates that the alternative hypothesis (Ha) was accepted. It means that there is the significant effect of using Cooperative Script significantly affects the students' reading comprehension at grade eleven SMA N 2 Pematangsiantar. Related to the conclusion, the researchers would like to give a recommendation for English teachers to consider Cooperative Script as a method in teaching reading to their students because it will be possible to make students interesting with the text and to comprehend the information within the text. The use of Cooperative Script is useful to increase students' comprehension in teaching reading. The 
success in teaching does not depend on the lesson program only, but more important is how the teacher present the lesson and uses various method to manage the class more lively and enjoyable.

\section{REFERENCES}

Ary, D., Jacobs, L.C., \& Sorensen, C. (2010). Introduction to Research in Education. Belmont, CA: Wadsworth, Cengage Learning.

Bolukbas, F., Keskin,F., \&Polat ,M. (2011). The Effectiveness of Cooperative Learning on the Reading Comprehension Skills in Turkish as a Foreign Language.Turkish Online Journal of Educational Technology-TEJOT.10 (4).330-335.

Creswell, J. W. (2011). Research Design Qualitative, Quantitative and Mixed Methods Approaches (4th ed.).Thousand Oaks, CA Sage.

Hatch, E., \& Farhady. (1982). Research design and statistics for applied linguistics. Cambridge: Newbury House Publisher.

Herman. (2014). An Experiential Function on Students' Genre of Writing. Jakarta: Halaman Moeka Publishing

Herman, Sibarani, J. K., and Pardede, H. (2020). The Effect of Jigsaw Technique in Reading Comprehension on Recount Text. Cetta: Jurnal Ilmu Pendidikan.Jayapangus Press, ISSN 2615-0891 (E). Vol. 3 No. 1 (2020). PP. 84-102

Hutajulu, F.S.L. and Herman .(2019). Analysis of Illocutionary Act in the Movie "You Are My Home” English Subtitle. Journal of English Educational Study. Volume 2 Issue 1 May 2019 Page 29-36. E-ISSN: 2655-0776

Pasaribu, B., Herman, and Hutahaean, D. T. (2020). Students' Difficulties in Translating Narrative Text From English Into Indonesia at Grade VIII of SMP Negeri 9 Pematangsiantar. Acitya: Journal of Teaching \& Education, 2(1), 13. Accessed from http://journals.umkt.ac.id/index.php/acitya/article/view/1311

Majid. M. (2014). Strategi Pembelajaran (Learning Strategy). Bandung, Indonesia: PT. Remaja Rosdakarya.

Riska, A.A.D., Marahaeni,, N., Suputra. D. E. P. (2018). The Effect of Cooperative Script Technique on the Eight Grade Students' Reading Comprehension at SMP Negeri 3 Banjar in Academic Year 2017/2018. E- Journal JPBI Universitas Pendidikan Ganesha Jurusan Pendidikan Bahasa Inggris. 
Sandiku, L. M. (2005). The Importance of Four Skills Reading, Speaking, Writing, Listening in a Lesson Hour. Europe Journal of Language and Literature.1(1).29-31.

Sihombing P. (2019). The Effect of using Jumble Letters in Teaching Vocabulary in Grade Eight Students of SMP Negeri 7 Pematangsiantar.International Journal of English Literature and Social Sciences (IJELS), 4(1), 37. Accessed from https://ijels.com/upload_document/issue_files/7-IJELS-JAN-2019-12TheEffectofusing.pdf

Slavin, R.E. (1996). Cooperative Learning. London: Longman. 